\title{
Main Approaches of Business English Teaching to Future Lawyers: A Case Study of Ukrainian Higher Institutions
}

\author{
Oksana P. Bykonia and Iryna V. Borysenko \\ Academy of the State Penitentiary Service, Chernihiv, Ukraine \\ https://orcid.org/0000-0002-8865-8792 \\ https://orcid.org/0000-0002-1191-3126
}

Tamila L. Gruba

Academician Stepan Demianchuk International University of Economics and Humanities, Rivne, Ukraine

https://orcid.org/0000-0002-9305-9372

Iurii L. Mosenkis and Dmytro O. Chystiak

Taras Shevchenko National University of Kyiv, Kyiv, Ukraine https://orcid.org/0000-0002-9957-0585

https://orcid.org/0000-0003-0081-7806

\begin{abstract}
The paper examines the difficulties teachers and students face while teaching and learning Business English in Ukrainian higher institutions; identifies and evaluates the problems of teaching English to future lawyers; determines the main methods and methodological approaches in teaching English for Specific Purposes and Business English to future lawyers. The authors describe a project recently piloted at the Academy of the State Penitentiary Service (Chernihiv, Ukraine) in which law students participated in the attitude survey toward learning the English language. In this study, feedback and quantitative methods were used to analyse the data of surveys. The teachers' and students' responses to survey questions were examined. The results showed a shift from a teacher-centred to a student-centred approach in university teaching and student preferences in learning English. The study calls for the enhancement of teaching the essential professional skills in English that students need to succeed in making their pathway choices and enable continuous growth throughout a legal career. Research findings are discussed with due regard to the surveyed students' needs and personality-oriented principles in legal education. The results indicate a need for methodological innovations that will support meaningful learning and boost the students' and cadets' productivity and efficiency of teaching and learning process. Despite the experimental group involving only the cadets and students majoring in "Law" and "Law enforcement", this methodology could be applied to teaching Business
\end{abstract}


English and English for Specific Purposes to a number of other specialities, in particular Economics, Psychology, Business, and International Relations.

Keywords: approaches; methods; Business English; English for Specific Purposes; teaching future lawyers; student-centred learning

\section{Introduction}

In recent years, the educational system of Ukraine is facing the dramatic changes aimed at implementing the agenda of large-scale reforms in professional training. The basic functions of the higher educational system are being tailored to suit the needs and expectations of the learner's personality as the main subject of the teaching process. However, in view of various challenges facing the teaching and learning of Business English in Ukrainian higher educational institutions, the consistent high failure rates in final, entrance or external evaluation examinations has reached a disturbing proportion. Every year an overwhelming number of students consider the English language to be one of the most difficult subjects. Needless to say, the cases of the students' poor performance at the examinations in English and Business English are not infrequent nationwide. This has obviously become an issue in higher education of Ukraine, as an examination in the English language is an important prerequisite for the students to pass at a certain level (B1, B2, C1) for applying to a higher educational institution and being eligible to be enrolled in the Bachelor's and Master's programmes. Our research is based on the principle which the Ministry of Education of Ukraine holds that a particular higher educational establishment has the institutional freedom to decide on its foreign language teaching aims and objectives and to design the optimal curricula to best meet the needs of its circumstances.

\subsection{Literature Review}

Contemporary researchers extensively dwell on various methods and methodological approaches as well as autonomy in teaching English for Specific Purposes and Business English context (Belcher, 2017; Bieliauskaite, 2014; Stefanowicz-Kocol \& Djordjevic, 2017; Selama, 2018). The scholars that have studied the problems of teaching English to future lawyers are Harvey (2000), Northcott and Brown (2006), Harper and Widodo (2018), etc. Thus, Northcott (2009) overviews a pedagogical perspective of teaching legal English, giving important insights about developing effective links between the employers and universities. Furthermore, Northcott and Brown (2006) focus on the legal translators and English law teachers, analyse legal seminar discourse, emphasising the high value of collaboration between language specialists and law lecturers that is beneficial for legal English educators in both teaching and law. Harvey (2000) points out the legal vocabulary as one instance of specialised language with a special focus on culture-specific terminology. Bilová (2016) suggests teaching students to focus on the indispensable parts of the lawsuit and use legal vocabulary practicing the case studies, which can enhance students' performance and motivation. However, partial issues of the problem of elaborating the efficient methodology for teaching English for Specific Purposes 
and Business English to the law students are not sufficiently addressed, leaving the gaps to be investigated. In this connection, the present paper examines the pedagogically-driven urge for the methodological innovations and effective teaching and learning technologies to bring the legal education in Ukraine in line with the worldwide standards. Also, the paper aims to bridge the gap between the collective learners' framework and the individual framework of knowledge acquisition that teachers' have to tackle.

In this regard, the role of the English language in law education is one of the key aspects of the quality training of students majoring in law. The quality training of efficient lawyers empowers them to cooperate with foreign legal entities, integrating the best legal practices into the Ukrainian context. This view is supported by the recent research in Nagovitsyn, Saltykova and Maksimova (2018). As for the learners' needs and incentives to study legal English, the researchers emphasise that the future lawyers study the English language to be competent in their work as to interact with their colleagues, clients, partners, to make use of the appropriate legal vocabulary, to explain legal contents in English, to conduct negotiations on legal issues; to draft contracts, to write claims, letters, emails on legal matters; to listen and watch the court proceedings; to be knowledgeable in English legal system; to process legal documents, papers, bulletins, reference literature in English; to prepare presentations and reports in English (Nagovitsyn, Saltykova \& Maksimova, 2018).

Teaching English to future lawyers is grounded on such educationalist approaches as the differential, the synergistic, the axiological, the cognitive, the communicative, the contextual, the professionally-oriented, the systemic, the competency-based, the reflexive, the psychoeducational (personality-oriented), etc. As for the differential approach in teaching English, it provides pedagogical differentiation of teaching, learning and a special way of organising an engaging educational process for the learners. Within the framework of this approach, the educational activity is managed taking into account typological, personalityspecific, individualised characteristics of the learners, including the interrelation of biological, psychological and socio-cultural factors in their dynamic combination. The teachers should assess the students' preferences and inclinations while organising their educational activity and rely on the learners' feedback. We agree with Yaroshenko (2019), that the main task of differentiation is not to bring all students to the unique standard at the end of the course, but to get them achieve the best possible results according to their abilities, individual peculiarities, interests and needs. Thus, Druzhchenko (2018) in her research shows the efficacy of the system of assignments designed to enhance in law students the English-language monological skills. It is shown that the application of the differentiated approach draws heavily on the personality developing of the law specialists. In fact, our study found that such a perspective concerns a close interplay of the learners' individual characteristics and their communicative skills, a way of thinking, mentality, motivational sphere, and professional standards. 
As maintained by Hall and Howard (2008), the fundamentals of this approach are synergic ideological unity of diversity and uniqueness, the value of the educational research in a sustainable society. This perspective is of a generally scientific nature, because all of its developing systems have the property of synergy, which presupposes a qualitative assessment of information; laying a special emphasis on creativity to promote the integration of knowledge, practical skills, and hands-on experience (The Law Society, 2018). So, both Ukrainian and foreign scholars consider that synergistic approach to be of great value in teaching English for Specific Purposes to future lawyers (Stojković, Tošić \& Nejković, 2017; Popova \& Petrova, 2017).

The axiological approach ensures maintaining, transferring, reproducing and developing culture by experience and education; contributes to the creation of optimal conditions for the integration of cultural, ethical and moral values, raising awareness of the learners' cultural needs, interests and abilities; contributes to the ability to perceive common features and differences between different cultures (Lehtonen, 2017; Valeev \& Kondratyeva, 2015). Within the framework of the axiological approach, the transfer of future lawyers' value standards as well as preserving their cultural and ethnic diversity in the process of learning the English language is seen as a pedagogically-enriching experience. The cognitive approach provides students with the comprehension of the English lexical units, the formation of the ability to explain the selection and using words and word combinations in the process of English communication; students' ability to distinguish the techniques they use and evaluate their effectiveness, etc. (Kurbakova, 2015; Sereda, 2017). To this end, Sereda (2017) maintains that this approach makes it possible to carry out the complex analysis of communication in view of the factors, revealing its nationally-specific components. It is important to emphasise that the English language plays an essential role in shaping the cognitive structures and their involvement in interaction, while preserving national and cultural identity and language diversity.

The communicative approach involves independent learning activities, aimed at setting and solving students' specific learning tasks using role/business games, problem situations, using various communication strategies. This approach contributes to expanding the objective of 'real-life' interaction in the classroom; enhancing language fluency; generating on-the-spot language performance; facilitating lifelong language learning. The renowned researchers that contributed to the elaboration of this approach in teaching the English language are Swan (1985), Savignon (1987), Nunan (1991), Ridge (1992), Richards (2006), Richards and Rodgers (2014), and others.

The contextual approach realises the students' gradual transition from educational activity to a quasi-professional activity (through business games, project work, etc.), then to a professional activity (through design and production practice). The strategies of the students' study help them to focus on problem-solving, using the context of law situations such as negotiating on legal issues; drafting contracts, discussing cases in English, etc. 
The professionally-oriented approach takes into account the future profession and interests of students of law specialities in the course of their learning English (Diachkova, 2014). A considerable attention is paid to the professionally-oriented texts for speaking, writing, listening and reading to teach Business English to the students.

It is important to stress that the systemic approach is an essential one in our study. This approach in to teaching a foreign language is used in a number of current researches. The systemic approach is oriented on the analysis of methodology as a certain structure. The essence of this approach is that studying Business English is a pedagogical system that incorporates structural and functional components. To successfully solve the problems of the future lawyers' vocational training, the systemic approach is a relevant one to organise students' curricular activity, which belongs to the category of systems as holistic entities consisting of interrelated elements.

In our research, we refer to the functional components of teaching Business English to future lawyers as organisational (i.e. organisational skills to implement an activity plan), constructive (i.e. constructive skills to create a real model of the planned activity), design (i.e. project skills to predict, to create an object as a certain integrity in the imagination, to determine the prognosis of professional activity), communicative (i.e. communication skills to interact with foreign partners in English), research (i.e. gnostic skills of analysing, studying, evaluating, etc.) and creative (i.e. creative skills to make up oral and written text), which are interdependent for the subjects of the educational activities (Figure 1).

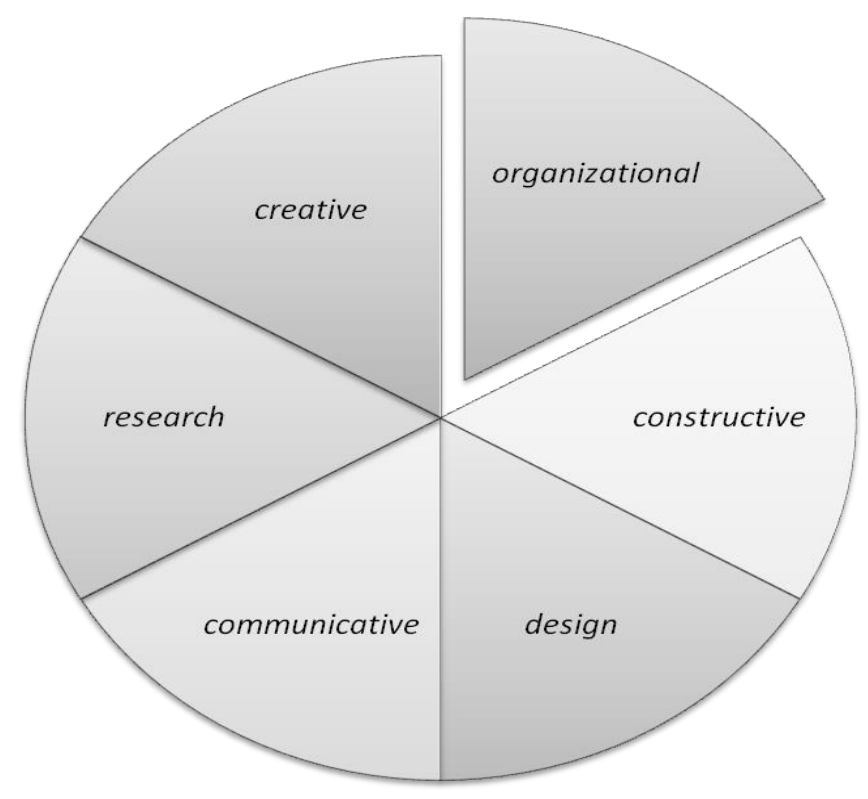

Figure 1: Functional components of teaching Business English to future lawyers

According to this approach, we maintain that the teacher and student interact both directly and indirectly. This interaction is carried out throughout the entire scope of independent mastering of the English-language competencies. Thus, the 
systemic approach allows to consider teaching Business English, in particular, the business rhetoric as a meaningful educational activity.

The systemic approach involves the system management of students' independent extracurricular learning activities in improving English. It is possible to plan this activity effectively, introduce and manage new learning technologies. Moreover, it is necessary to take into account the purpose and structure of the entire syllabus of learning English. However, monitoring and assessing the students' performance in adjusting their Business English speaking and writing competencies to the needs of their future profession should be conducted from the initial stage through the final one.

The competency-based language teaching develops in students a set of key competencies through the performance of language activity; it is considered to be one of the key approaches that expands, deepens, and complements the other ones. Thus, Zenya (2011) relates the competency-based approach to a personality-oriented approach, since the important pedagogical condition for achieving the goal of education is the acquisition of certain competencies in teaching the academic subjects based on individual experience.

One of the key concepts of the process of updating the Ukrainian higher education context is the concept of competence as a person's system of knowledge, skills and abilities and personal attitude to the subject of the learning activity. The level of competence of a specialist should ensure his/her harmonious interaction with society. The level of the foreign language competence of a specialist in this area depends on the further development of professional skills to use a foreign language, in particular, English for Specific Purposes, in real intercultural communication.

The fundamental element of the reflexive approach is the concept of reflection, which is interpreted differently in philosophical, pedagogical, sociological and psychological perspectives. It is interpreted as the process of lifelong development; the special ability of the human mind to construct world views; awareness of the personality as perceived by the communication partners, for rethinking the ideas concerning professional activity (Popovska \& Pirsl, 2017). One of the important approaches to addressing the task of teaching English to law students is referred to as the personality-oriented approach, which has personal and activity components that are interrelated (Sayitova, 2020). As the researcher maintains, it is crucial to devote more effort to the learners' individual and psychological features, their age, national peculiarities and interests; developing a system of individualised tasks to enhance the student's performance.

In sum, with due regard to all of the above-mentioned approaches, in accordance with the subject of our research, we aimed at determining what approaches of Business English teaching to future lawyers should be used in the university context of Ukrainian legal higher institutions. 


\subsection{Research Objective}

The purpose of the article is to determine the methods and methodological approaches in teaching English for Specific Purposes and Business English to future lawyers in the Ukrainian legal higher educational institutions. To effectively address this purpose, the problem statement is formulated as follows. The role of English for Specific Purposes in the development of essential skills for a legal career requires a closer attention to enable the future lawyers' continuous growth. To this end, the research aims at highlighting what should the educational process in general and the Business English in particular be centred on so as to enable each student choose their own educational trajectory and take into account their feedback.

From the practical perspective, the paper aims at distinguishing specific methods in teaching English for Specific Purposes at higher educational institutions in Ukraine to enhance the students' personal performance opportunities and to ensure the future lawyers' sustainable success in the labour market. From the theoretical perspective, the paper dwells on the range of variables to improve the quality of the future lawyers' training with due regard to the need to analyse the functional changes in further professional activity. To achieve this objectives, the following tasks were set to outline the approaches of teaching Business English to future lawyers that can be used in the university educational context; to analyse the attitudes and opinions of the future lawyers toward studying Business English using different methods and technologies; to assess the students' needs and render their opinions towards learning Business English and having obtained the experimental results, to devise the recommendations for a study model sensitive to needs of the future lawyers in higher educational institutions.

The hypothesis of our paper is grounded on the presumption that the utilisation of the specific pedagogically-driven approaches and methods outlined in the study and specified in students' surveys and feedback, will boost the learners' motivation and performance thus contributing to sustainable growth throughout a legal career.

\section{Methodological Framework}

The study was a continuous succession of the three stages: 1) the empirical stage - to study the current state how the teachers instruct the future lawyers in Business English at legal higher institutions, the current state of the students' learning English and Business English; 2) the experimental stage - to do questionnaires in needs analysis; (3) the analytical stage - to process the collected experimental data. First, we conducted the surveys among the fiftythree teachers of English from Ukrainian legal higher institutions to find out what methods and approaches they use in teaching English, Business English and English for Specific Purposes to future lawyers. A sample Size Calculator (Raosoft, n/d) was used to determine the size of a representative sample to ensure the quality and reability of the experiment results given that $n$ (population size) $=206$, confidence interval $=2.34$, and $\mathrm{e}=0.05$ if confidence level $=95 \%$. 
To ensure reability of the observation reports, behavioural code description was developed and three assessors were hired to take records. Data was simultaneously collected be all assessors on each separate session. Kappa Online Calculator (n./d.) was used to assesses the inter-rater reliability of three raters drawn from the observation reports, evaluation sheets, student attendance records. The kappa coefficient was 0.74 which was substantial and proved that the measurements were reliable (Raosoft, $\mathrm{n} / \mathrm{d}$ ). The data were calculated in percents as presented in Table 1.

Table 1: Shift in teachers' preferences in teaching English

\begin{tabular}{|ll|c|}
\hline \multicolumn{1}{|c|}{ approaches used } & teachers/tutors of English, \% \\
\hline$\checkmark$ & differential & $35 \%$ \\
\hline$\checkmark$ & synergistic & $42 \%$ \\
\hline$\checkmark$ & axiological & $44 \%$ \\
\hline$\checkmark$ & cognitive & $47 \%$ \\
\hline$\checkmark$ & communicative & $94 \%$ \\
\hline$\checkmark$ & contextual & $51 \%$ \\
\hline$\checkmark$ & professionally-oriented & $100 \%$ \\
\hline$\checkmark$ & systemic & $69 \%$ \\
\hline$\checkmark$ & competency-based & $78 \%$ \\
\hline$\checkmark$ & reflexive & $59 \%$ \\
\hline$\checkmark$ & personality-oriented & $44 \%$ \\
\hline$\checkmark$ & other & $35 \%$ \\
\hline
\end{tabular}

The following stage of our research was to determine what approaches of teaching Business English to future lawyers should be used in the university educational context. Also, it was necessary to analyse the attitudes and opinions of the future lawyers toward studying Business English using different methods and technologies. The sample of this study comprised 98 first-year students and cadets studying in the Academy of the State Penitentiary Service (Chernihiv, Ukraine). We surveyed two groups of the cadets and students at the first (bachelor) level of higher education in the field of "Law" and "Law enforcement". The first group consisted of 48 cadets ( 37 males and 11 females) who studied English at the Law department. The second group consisted of 50 students (34 males and 16 females) who studied English at the Law enforcement department. The sample comprised only first-year cadets and students at the first (bachelor) level of higher education in the field of "Law" and "Law enforcement" who studied English in the Academy of the State Penitentiary Service. The questionnaire was distributed to the sample of all the first-year cadets and students $(n=98)$ in the Academy. 
To assess the students' needs and render their opinions towards learning Business English, an attitude scale was used as the main tool of the study. The obtained data of teaching Business English to future lawyers were viewed in the present study as the independent variables, whereas the future lawyers' achievements were analysed as the dependent variables.

We prepared several sets of questions focusing on the students' interests, challenges, creative ability, proficiency, learning ability, effectiveness, performance and practical relevance regarding English and Business English as academic subjects in the Academy of the State Penitentiary Service. We focused on the attitudes of the students to the English language as an academic subject, and the methods and approaches designated to be applied at the English classes (see Table 2).

Table 2: The attitude of the students to learning English

\begin{tabular}{|c|c|c|c|}
\hline$\#$ & Items & $\begin{array}{l}\text { Positive, } \\
\%\end{array}$ & $\begin{array}{c}\text { Negative, } \\
\%\end{array}$ \\
\hline 1 & $\begin{array}{l}\text { Do you prefer fulfilling some differentiated tasks, } \\
\text { assignments, exercises while learning English and } \\
\text { Business English? }\end{array}$ & 59 & 41 \\
\hline 2 & $\begin{array}{l}\text { Would you rather be taught according to your } \\
\text { peculiarities such as creativity, trainability, interests, } \\
\text { proficiency, performance, according to which the forms } \\
\text { and methods of teaching English are selected and } \\
\text { differentiated? }\end{array}$ & 76 & 24 \\
\hline 3 & $\begin{array}{l}\text { Do you have any difficulties in the process of } \\
\text { adaptation and socialisation at the English classes? }\end{array}$ & 46 & 54 \\
\hline 4 & $\begin{array}{l}\text { Do you develop your tolerance to social, cultural, and } \\
\text { personal differences while studying English in the } \\
\text { Academy? }\end{array}$ & 44 & 56 \\
\hline 5 & $\begin{array}{l}\text { Do you develop your ability of teamwork skills and } \\
\text { readiness for active interaction with the other students } \\
\text { and cadets, especially while interacting in oral and } \\
\text { written English? }\end{array}$ & 53 & 47 \\
\hline 6 & $\begin{array}{l}\text { Is it important to study the culture of English-speaking } \\
\text { lawyers? }\end{array}$ & 63 & 37 \\
\hline 7 & $\begin{array}{l}\text { Would you prefer to study the differences between } \\
\text { English-speaking and Ukrainian cultures in the legal } \\
\text { sphere at your English classes? }\end{array}$ & 74 & 26 \\
\hline 8 & $\begin{array}{l}\text { Should you have the ability to explain the selection and } \\
\text { the usage of the words and word combinations in the } \\
\text { process of English communication, in particular in } \\
\text { professional situations? }\end{array}$ & 57 & 43 \\
\hline 9 & $\begin{array}{l}\text { Do you often have difficulties to understand English } \\
\text { legal terminology, vocabulary, specialised lexical units? }\end{array}$ & 62 & 36 \\
\hline 10 & $\begin{array}{l}\text { Do you frequently use various speech strategies while } \\
\text { communicating in English for Specific Purposes? }\end{array}$ & 71 & 27 \\
\hline 11 & $\begin{array}{l}\text { Do you often solve problem situations connecting with } \\
\text { legal profession in English? }\end{array}$ & 56 & 44 \\
\hline 12 & Do you use the strategies to focus on problem solving? & 59 & 41 \\
\hline
\end{tabular}




\begin{tabular}{|c|c|c|c|}
\hline 13 & $\begin{array}{l}\text { Is it difficult to understand the context of legal oral and } \\
\text { written situations in English? }\end{array}$ & 68 & 32 \\
\hline 14 & $\begin{array}{l}\text { Does the contextual instruction correlate your English } \\
\text { learning materials and 'real-life situations? }\end{array}$ & 67 & 33 \\
\hline 15 & $\begin{array}{l}\text { Is it important to focus on your future profession } \\
\text { during your English language classes? }\end{array}$ & 81 & 19 \\
\hline 16 & $\begin{array}{l}\text { Would you like to be a participant in business and } \\
\text { professional situations at your English classes? }\end{array}$ & 92 & 6 \\
\hline 17 & $\begin{array}{l}\text { Do you prefer to study English according to a certain } \\
\text { system including patterns, units, steps, etc.? }\end{array}$ & 82 & 18 \\
\hline 18 & $\begin{array}{l}\text { Do you want to be taught English in a structured, } \\
\text { creative, and meaningful way? }\end{array}$ & 100 & 0 \\
\hline 19 & $\begin{array}{l}\text { Does the teacher of English explain how you should } \\
\text { develop English competence? }\end{array}$ & 51 & 49 \\
\hline 20 & Do you know any English competences? & 32 & 68 \\
\hline 21 & $\begin{array}{l}\text { Do you usually check your homework using keys (if } \\
\text { there are keys after the tasks and exercises)? }\end{array}$ & 71 & 29 \\
\hline 22 & $\begin{array}{l}\text { Can you analyse and evaluate the process of your } \\
\text { independent study in English? }\end{array}$ & 43 & 57 \\
\hline 23 & $\begin{array}{l}\text { Do you prefer doing tasks in English according to your } \\
\text { individual and psychological features? }\end{array}$ & 56 & 44 \\
\hline 24 & $\begin{array}{l}\text { Do you agree that your teacher of English should take } \\
\text { into account the individual characteristics of each } \\
\text { student in teaching English and Business English? }\end{array}$ & 80 & 20 \\
\hline
\end{tabular}

\section{Results}

Thus, the questionnaire comprising 24 questions on the 2-point scale ranging from "Strongly agree" to "Disagree" was developed. The survey questions were designed so as to include perspectives on several methodological approaches in teaching English and Business English, in particular, the differential approach (Questions 1-2), the synergistic approach (Questions 3-5), the axiological approach (Questions 6-7), the cognitive approach (Questions 8-9), the communicative approach (Questions 10-11), the contextual approach (Questions 12-14), the professionally-oriented approach (Questions 15-16), the systemic approach (Questions 17-18), the competency-based approach (Questions 19-20), the reflexive approach (Questions 21-22) and the personality-oriented approach (Questions 23-24) (See Table 2).

The sample represents the students and cadets from the Academy of the State Penitentiary Service (Chernihiv, Ukraine). The researchers selected the subjects focusing on the areas perceived as significant to the study of English and Business English. Furthermore, the attitude scale was analysed for the future lawyers studying in Ukrainian higher institutions. While conducting the survey, it was assumed that the students and cadets were able to understand English to a sufficient degree to interpret the attitude scale and maintain academic integrity in answering the questionnaire. The questions on the scale asked the students and cadets to describe their attitudes toward learning English and how they see the syllabus design of this subject in the Academy. The survey was conducted in September and October 2019. A statistically significant difference was found at the level of $p<0.05$. 
According to the results of this survey, we found out that a number of students and cadets prefer to be taught according to their individual peculiarities such as: creativity, trainability, interests, proficiency, performance in accordance to which the forms and methods of teaching English are tailored (76\%); to develop their ability of teamwork skills and readiness for communication with the other students and cadets, especially while interacting in oral and written English (63\%); to study the culture of English-speaking lawyers (74\%); to be capable of explaining the usage of English words and word combinations in professional situations (57\%). The surveyed students and cadets pointed out the importance of focusing on their future profession at the English classes $(81 \%)$ and the desire to engage practicing business and professional situations (92\%). The surveyed students and cadets emphasised that they wanted to study English according to a structured system including patterns, units, steps, etc. (82\%) and to be taught English in a systemic, creative, and meaningful way $(100 \%)$. The surveyed students expressed an opinion that the teacher of English should explain how students can develop English competency (51\%). At the same time, they did not know much about English competencies (66\%). Fifty-four percent of the surveyed supported the idea of the necessity to develop their tolerance to social, cultural, and personal differences while studying English in the Academy. The interviewees mentioned that they had difficulties to understand English legal vocabulary $(62 \%)$ and the context of legal oral and written proceedings in English (68\%) and in the process of their adaptation and socialisation at the English classes (46\%).

We point out the fact that they usually checked their homework using keys (if available after the tasks and exercises) (71\%). However, we emphasise that only $43 \%$ of them could analyse and evaluate the process of their independent study of the English language. Fifty-six percent of the students and cadets agreed that their teacher of English should take into account the individual peculiarities of each particular student while teaching English and Business English and assign the learners with individualised tasks in the subject according to their psychological abilities and features (80\%). The results indicated statistically significant differences in being motivated to use differentiated tasks, assignments, exercises while learning English and Business English (59\%); various communicative strategies while interacting in English for Specific Purposes (71\%) and the strategies to focus on problem-solving (59\%). Following that, the population size of $98(\mathrm{e}=05) 100 \%$ of confidence level was calculated by the Sample Size Online Calculator (Raosoft, n/d).

\section{Discussion}

This research utilises both empirical and statistical methods for the study of what methods and approaches of teaching English and Business English to future lawyers are used in Ukrainian legal higher education institutions. The mixed-method approach was utilised in order to fulfill the research objective. With this in mind, we drew on the quantitative features to yield the results as for the overall statistics and obtained qualitative particulars to highlight the details. The research deals with the organisation of teaching English to future lawyers 
drawing on such approaches as the differential (the differentiating content of teaching English, the learning process, aids and products, or the creation of an integrated and intercultural learning environment, monitoring student progress, ongoing assessment, helping students develop the competences to achieve their goals), the synergistic (giving students considerable chances to gather, collate and validate their learning experiences which are realised by various methods and techniques), the axiological (involving the transfer of students value samples in studying foreign language on the basis of cultural values), the cognitive (increasing students' motivation to study professional vocabulary), the communicative (involving in real oral and written communication contexts/situations), the contextual (constructing meaning/definition based on their own experiences, anchoring teaching in the diverse life context), the professionally-oriented (supplying the students with professionally-oriented texts for speaking, writing, listening and reading in Business English), the systemic (organizing students' learning activity which belongs to the category of systems, as holistic entities consisting of interrelated elements), the competencybased (developing a set of key competences through the performance of language activity), the reflexive (personality-oriented) (engaging the student and stimulating reflection on their activity).

The present study determined that in teaching English to future lawyers, the teachers predominantly prefer to use professionally-oriented, communicative, contextual, systemic, competency-based and reflexive approaches. As mentioned above, one of the key goals of teaching legal English is sensitivity to the needs to develop the syllabi aimed at providing a specific group of students with the specifically tailored tools which they need or desire. Presumably, such methodological moves will support meaningful learning and boost the students' and cadets' productivity and efficiency of teaching English. With this current study, we determine that the students and cadets feel more positive when the teacher of English takes into account the individual characteristics of each student while teaching English and Business English and adjusts the English assignments according to the individual and psychological features of the particular group of students. Besides, the effective and efficient instruction in English calls for the teacher to highlight how to develop English competencies; the course-related content should consider the differences between Englishspeaking and Ukrainian cultures in the legal sphere, drawing on the learners' individual peculiarities, such as creativity, trainability, interests, proficiency, performance, etc. Thus, the surveyed prefer to be taught English and Business English with the application of the differential, axiological, communicative, professionally-oriented, systemic, reflexive and personality-oriented approaches. To compare the study of the teachers' and students' opinions about learning and teaching English, we made up Table 3. 
Table 3: Shift in approaches to learning and teaching English

\begin{tabular}{|l|c|c|}
\hline \multicolumn{1}{|c|}{ approaches } & teachers/tutors of English, \% & $\begin{array}{c}\text { students and } \\
\text { cadets }\end{array}$ \\
\hline differential & $\checkmark$ & $\checkmark$ \\
\hline synergistic & $\checkmark$ & - \\
\hline axiological & $47 \%$ & \\
\hline cognitive & $\checkmark$ & $\checkmark$ \\
\hline communicative & $\checkmark$ & $\checkmark$ \\
\hline contextual & $\checkmark$ & $\checkmark$ \\
\hline professionally-oriented & $\checkmark$ & \\
\hline systemic & $\checkmark$ & $\checkmark$ \\
\hline competency-based & $\checkmark$ & $\checkmark$ \\
\hline reflexive & & \\
\hline personality-oriented & $35 \%$ & \\
\hline other & & \\
\hline
\end{tabular}

Overall, the teachers, students and cadets in both groups chose the same approaches as differential, axiological, communicative, professionally-oriented, systemic, reflexive and personality-oriented ones. Furthermore, the students and cadets' results indicated the importance of taking into account the individual characteristics of each student while teaching English and Business English and preparing the assignments in English according to their individual and psychological peculiarities; explaining how to develop English competencies; showing the differences between English-speaking and Ukrainian cultures in the legal sphere during English classes.

\section{Conclusions}

To fully realise the goals and objectives of the challenges of today's society, the effective functioning of the lawyer in the labour market calls for the search of effective technologies for teaching English. The findings obtained from this study indicate that teachers do not consistently use the differential, synergistic, axiological, cognitive, personality-oriented approaches. The surveyed maintained that it was difficult to ensure more attention to individual and psychological peculiarities, age, national specificity and interests of students, and creating a system of exercises and tasks that take into account the students individual characteristics to enhance their performance opportunities.

Research findings are discussed with due regard to the surveyed students' needs and personality-oriented principles in teaching law students. The results appeal for certain methodological innovations that will support meaningful learning 
and boost the students' and cadets' productivity and efficiency of teaching and learning process. In the light of the findings of the current study, the training of a modern specialist calls for the adaptation of the syllabus and overall educational process to individual peculiarities of each student, enabling them to choose an educational trajectory. University teachers have to deal with the controversy of conducting the educational process in the collective learners' framework and the obviously individual framework of knowledge acquisition. Therefore, as our research has showed, the differentiated approach to learning a foreign language is aimed at making the most of the individual psychological, cognitive, motivational characteristics of the future lawyers. Furthermore, the most effective prerequisites for the development of professional determination, self-awareness, legal skills and abilities are achieved optimally and consistently by way of applying the personality-oriented principles in teaching law students.

\section{Limitation and Study Forward}

The overriding limitation of this study was an involvement in the research of one institution only. Another limitation was the specialisation of the cadets and students who majored in law. In the further research, we will study the level of English of students and cadets to measure their progress in Business English, create an entry test and a final test to measure their English communicative competency and prepare exercises and tasks focusing on the interest, difficulty and effectiveness toward learning Business English in legal higher institutions according to the above-mentioned methods and approaches.

\section{Acknowledgements}

This research design was elaborated with the involvement of the English language teachers from the universities in Chernihiv, Kyiv, Lvyv, Nizhyn, Dnipro, Odesa, and Ternopil (Ukraine). Furthermore, the English language instructors from the Academy of the State Penitentiary Service of Ukraine conducted this research. We maintain that the further study with varied cohorts of participants (junior as well as senior cadets and students, university tutors and lecturers broken down by the study programme, etc.) could yield new representative data. Also, more extensive quantitative research could further enrich this study.

\section{References}

Belcher, D. (2017). Recent developments in ESP theory and research: Enhancing critical reflection and learner autonomy through technology and other means. In $\mathrm{N}$. Stojković, M. Tošić, \& V. Nejković (Eds.), Synergies of English for Specific Purposes and Language Learning Technologies (pp. 2-19). Cambridge, UK: Cambridge Scholars Publishing.

Bieliauskaitè, J. (2014). On the way to professionalism - the promotion of law students' academic integrity. Procedia - Social and Behavioral Sciences, 116, 4229-4234. https://doi.org/10.1016/j.sbspro.2014.01.922

Bilová, S. (2016). Case briefs in legal English classes. Studies in Logic, Grammar and Rhetoric, 45(58), 7-20. https:/ / doi.org/10.1515/slgr-2016-0012

Diachkova, Y. O. (2014). The criteria of assessment of the level of formation of the professional English speaking skills of the future lawyers. Science and Education a New Dimension. Pedagogy and Psychology, 8, 62-66. 
Druzhchenko, T. (2018). Teaching English monologic oral production to law students: differentiated approach. Ars Linguodidacticae, 2(1), 76-82.

Hall, B., \& Howard, K. (2008). A synergistic approach: conducting mixed methods research with typological and systemic design considerations. Journal of Mixed Methods Research, 2(3), 248-269.

Harper, J., \& Windodo, H. P. (2018). 10 On the design of a global law English course for university freshmen: a blending of EGP and ESP. The European Journal of Applied Linguistics, 7(1), 2018, p. 173-190.

Harvey, M. (2000). A beginner's course in legal translation: the case of culture-bound terms. Retrieved from http://www.tradulex.com/Actes2000/harvey.pdf

Kurbakova, S. (2015). Cognitive aspect of intercultural communication. Journal of Language and Education, 1(3), 52-62.

Lehtonen, T. (2017). "You will certainly learn English much faster at work than from a textbook." - Law students learning English beyond the language classroom. System, 68, 50-59. https://doi.org/10.1016/j.system.2017.06.013

Nagovitsyn, R., Saltykova, M., \& Maksimova, M. (2018). A synergistic approach to the promotion of foreign students' socialization and adaptation to the educational environment of higher educational institutions. Novosibirsk State Pedagogical University Bulletin, 8(6), 7-22. http://dx.doi.org/10.15293/2226-3365.1806.01

Northcott, J. (2009). Teaching legal English: Context and cases. In D. Belcher (Ed.), English for specific purposes: Theory and practice (pp. 165-185). Ann Arbor, MI: University of Michigan Press.

Northcott, J., \& Brown, G. (2006). Legal translator training partnership between teachers of English for legal purposes and legal specialists. English for Specific Purposes, 25, 358-375.

Nunan, D. (1991). Communicative tasks and the language curriculum. TESOL Quarterly, 25(2), 279-295.

Popova, N. O., \& Petrova, O. B. (2017). English for law university students at the epoch of global cultural and professional communication. Oberih, 138, 237-246.

Popovska, S., \& Pirsl, D. (2017). ESP teacher's transforming profile. In N. Stojković, M. Tošić, \& V. Nejković (Eds.), Synergies of English for Specific Purposes and Language Learning Technologies (pp. 152-164). Cambridge, UK: Cambridge Scholars Publishing.

Raosoft. (n/d). Sample size Calculator. Retrieved from http://www.raosoft.com/samplesize.html

Richards, J. C. (2006). Communicative language teaching today. New York, NY: Cambridge University Press.

Richards, J., \& Rodgers, T. (2014). Approaches and Methods in Language Teaching (3 ${ }^{\text {rd }}$ ed.). Cambridge, UK: Cambridge University Press.

Ridge, E. (1992). Communicative language teaching: Time for review? Stellenbosch Papers in Linguistics Plus, 21, 95-108. https:// doi.org/10.5842/21-0-533

Savignon, S. J. (1987). Communicative language teaching. Theory into Practice, 26(4), 235242. https://doi.org/10.1080/00405848709543281

Sayitova, K. H. (2020). The role of personality-oriented approach in the process of education. Theoretical and applied science, 3(83), 190-192.

Selama, S. A. (2018). Autonomous learning in an ESP context: students' attitudes, readiness and efforts: A case study. Cahiers de Linguistique et Didactique, 1(7), 177200. 
Sereda, A. (2017). Cognitive-discourse approach as a methodology for the analysis of intercultural communication. The Journal of V. N. Karazin National University. Series: Theory of Culture and Philosophy of Science, 57, 48-52.

Stefanowicz-Kocoł, A., \& Djordjevic, D. (2017). Changing needs of the ESP students. In N. Stojković, M. Tošić, \& V. Nejković (Eds.), Synergies of English for Specific Purposes and Language Learning Technologies (pp. 20-22). Cambridge, UK: Cambridge Scholars Publishing.

Stojković, N., Tošić, M., \& Nejković, V. (Eds.). (2017). Synergies of English for Specific Purposes and Language Learning Technologies. Cambridge, UK: Cambridge Scholars Publishing.

Swan, M. (1985). A critical look at the Communicative Approach (1). ELT Journal, 39(1), 2-12. https:// doi.org/10.1093/elt/39.1.2

The Law Society. (2018). Future skills for law. Retrieved from https://www.lawsociety.org.uk/support-services/research-trends/horizonscanning/future-skills-for-law/

Valeev, A. A., \& Kondratyeva, I. G. (2015). Axiological Approach to the Development of Students' Intercultural Competences by Foreign Language Means. Procedia, Social and Behavioral Sciences, 191, 361-365. https:// doi.org/10.1016/j.sbspro.2015.04.377

Yaroshenko, O. (2019). On the necessity of implementing the differentiation approach to teaching foreign languages at higher educational institutions. Pedagogy of formation of creative personality in higher and secondary schools, 64(2), 161-167.

Zenya, L. (2011). Theoretical and methodological bases of future teachers' preparation for teaching of foreign languages to students of profile school. Horlivka, Ukraine: State Pedagogical Institute. 